\title{
UTILIZATION OF ARDUINO-BASED BLUETOOTH CONNECTION FOR ELECTRONIC EQUIPMENT CONTROL WITH VOICE COMMANDS
}

\author{
Hafdiarsya Saiyar \\ Program Studi Teknologi Komputer \\ Universitas Bina Sarana Informatika \\ hafdiarsya.hyr@bsi.ac.id
}

\begin{abstract}
Abstrak
Peralatan elektronik menjadi kebutuhan sehari-hari pada kehidupan manusia, namun tak jarang kita memakai peralatan elektronik secara berlebihan ataupun tidak efektif dan menjadi permasalahan utamanya adalah faktor lupa dan malas mematikan peralatan elektronik. Hal ini membuat pemborosan dalam menggunakan listrik sehingga biaya yang dibebankan pun menjadi lebih besar dan resiko terbesar adanya kontak arus yang menyebabkan kebakaran jika kita lalai dalam menggunakan penerangan. Maka dari itu penulis mencoba membuat alat pengendali peralatan elektronik dengan perintah suara yang dihubungkan dengan bluetooth pada smartphone sehingga pengguna bisa memberikan perintah untuk mengaktifkan ataupun mengnonaktifkan peralatan elektronik dengan perintah suara. Metode penelitian yang digunakan adalah observasi langsung terhadap objek yang terpilih yaitu rumah penulis serta melakukan studi pustaka yang berkaitan dengan mikrokontroler Arduino. Mikrokontroller Arduino berperan sebagai pengendali utama yang terhubung ke modul relay dan modul relay terhubung ke steker listrik. Selain itu Arduino juga terhubung pada bluetooth sebagai tempat untuk memproses perintah yang masuk. Tujuan penelitian ini adalah menghasilkan suatu alat yang dapat mempermudah dalam menghidupkan atau mematikan peralatan elektronik dengan perintah suara melalui smartphone android dengan memanfaatkan koneksi bluetooth berbasis Arduino.
\end{abstract}

Kata kunci: Android, Arduino, Bluetooth, Elektronik, Smartphone

\begin{abstract}
Electronic equipment is a daily necessity in human life, but not infrequently we use electronic equipment excessively or ineffectively and the main problem is the factor of forgetting and being lazy to turn off electronic equipment. This makes wasteful use of electricity so that the costs charged are greater and there is the greatest risk of contact currents causing fire if we neglect to use lighting. Therefore, the author tries to make a control device for electronic equipment with voice commands connected to Bluetooth on a smartphone so that users can give commands to activate or deactivate electronic equipment with voice commands. The research method used is direct observation of the selected object, namely the author's house, and conducting literature studies related to the Arduino microcontroller. The Arduino microcontroller acts as the main controller connected to the relay module and the relay module connected to the power plug. In addition, Arduino is also connected to Bluetooth as a place to process incoming commands. The purpose of this research is to produce a tool that can make it easier to turn on or turn off electronic equipment with voice commands via an Android smartphone by utilizing an Arduino-based Bluetooth connection.
\end{abstract}

Keywords: Android, Arduino, Bluetooth, electronic, smartphone

\section{INTRODUCTION}

In this day and age, we often find electronic equipment in every home, but the main cause of the problem is the factor of forgetting and being lazy to turn off electronic equipment (Budiarto \& Hadi, 2020). As users of electrical energy, many people forget to turn off electronic equipment at home. when they are not in use or when they are traveling outside, this results in a waste of electrical energy or it can cause a fire.

Research conducted with digital voice processing is controlled by an application to recognize detected voice commands (Rusdi \& Yani, 2018), which are commonly referred to as voice recognition. The technology works by capturing the 
human voice, which is converted into a digital format so that it can be translated into the system. The system then compares the information entered in a digital format with the existing sound database. Further research was carried out by (Lubis, Gultom, \& Annisa, 2019) The results obtained are increased comfort and convenience for people with physical disabilities or the elderly who have difficulty standing or cannot reach the light switch. After the Bluetooth device can be used on an Android smartphone, the device can work normally.

Furthermore, other research was carried out by (Faroqi, WS, \& Nugraha, 2016) Research that uses voice signal data is usually called speech processing and aims to create a system that can recognize sounds in the form of sentences for future use in electronic technology. Sound processing also needs to go through various processes, such as sampling, extraction, and learning. Through the process of sound signal extraction, its characteristics can be known. There are several commonly used feature extraction methods, but the linear predictive coding (LPC) method is used in this study. LPC is used because the extraction system uses the human auditory system as a filter for information retrieval. Then, because the adaptive neuro-fuzzy interference system (ANFIS) can carry out a probabilistic analysis and then generate a response based on parameters, the adaptive neurofuzzy interference system (ANFIS) will carry out the learning and speech recognition process itself.

GAP analysis is that it can implement to other electronic equipment in previous researchers only lights, now coupled with fans. The increase in the number of lamps is propagated by placing the location of the electronic equipment. With the creation of a control device with voice commands, the process of turning on and off is easier. In addition, it helps save electrical energy and prevents fires caused by laziness and forgetting to turn off electronic equipment.

The purpose of this research is to produce a tool that can make it easier to turn on or turn off electronic equipment with voice commands via an Android smartphone by utilizing an Arduino-based Bluetooth connection. (Mandey \& Simbolon, 2018)

\section{RESEARCH METHODS}

In collecting data and information, the author uses several research methods, including:

1. Observation Method

The author makes direct observations of the selected object, namely the author's house, where the author observes what tools are good to make it easier for the writer.

\section{Literature review}

To complete the required data, the authors conducted a literature study, namely by reading other data sources available in public libraries and journals related to Microcontrollers and Arduino for tool planning.

\section{A. Block Diagram}

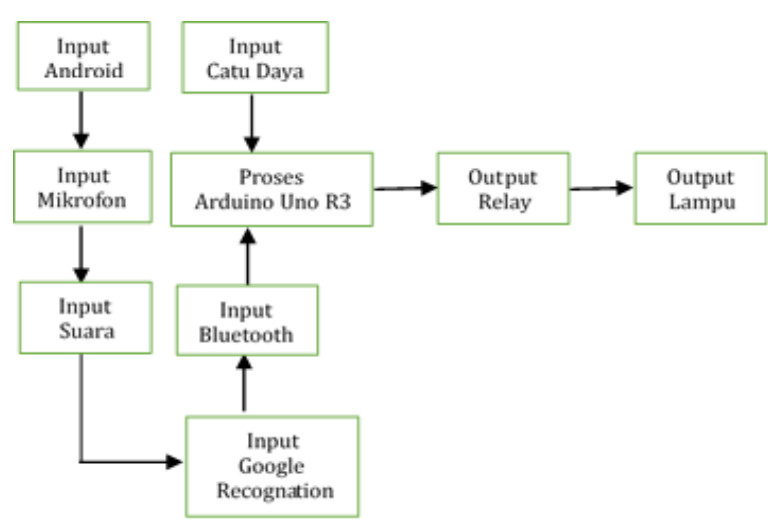

Figure 1. Block Diagram

The explanation of Figure 1 is as follows:

1. Input

The input component is an input component that will be processed. The input components consist of: The input component is an input component that will be processed. The input components consist of:

a. The power supply is a device or hardware device capable of delivering power or electric voltage directly from a power supply voltage to another voltage (Destiarini \& Kumara, 2019)

b. Android is a new generation of mobile platforms that provide opportunities for developers to develop as expected. The operating system that underlies Android is a license under the GNU, General Public License Version 2 (GPLv2) which is commonly known as Copyleft. The term copyleft is a license that any repairs by third parties must continue to fall under the license terms (Fatoni \& Rendra, 2014)

c. The microphone functions as a transducer, which can convert human sound waves into electrical signals (Aulia, Lifwarda, \& Yustini, 2018). A smartphone is the development of a mobile phone that is added with features such as personal computer features such as email, personal organizer, and additional connectivity such as wifi and Bluetooth that can be installed on the device.(Warangkiran, Kaunang, Lumenta, \& St, 2014). Smartphone microphone functions as a tool to detect voice commands. 
d. Bluetooth HC-05 is a wireless (wireless) communication technology that operates in the 2.4 GHz unlicensed ISM (Industrial, Scientific, and Medical) frequency band using a frequency hopping transceiver capable of providing realtime voice and data communication services between hosts. to host Bluetooth with a limitedservice range.(Sentosa, Putra, \& Wulandari, 2017)

e.AMR_Voice application as an interface with the Google Voice Command Recognition System which can be downloaded on the Google play store. This application functions to change the voice and convert it into electronic data (digital) which can be understood by the Arduino Uno Microcontroller.(Dani, Adriansyah, \& Hermawan, 2016)

2. Process

The process is the main component that plays a role in processing data or voice commands from the smartphone microphone and after that it produces output. In this process, the author uses the Arduino Uno microcontroller(Purnamasari \& Rezasatria, 2019).

3. Output

Output is the output of all processes that are run. The resulting output, namely electronic equipment such as light bulbs or fans, will become active from previously inactive or from inactive to active.

a. Relay functions as a switch to connect or disconnect the flow of electric current which is controlled as an output from the microcontroller.(Maulana \& Rachmat Adi Purnama, 2017)

b. A lamp is a device that produces light (Manaor, Efendi, \& Informatika, 2017)

\section{B. Schematic of Tool Circuit}

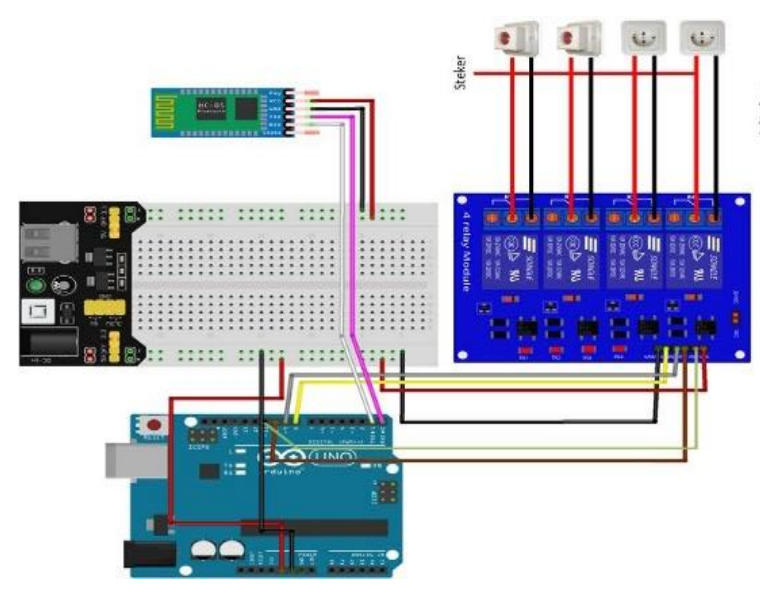

Figure 2. Series of tools
The explanation of Figure 2 is as follows:

This circuit is a control system for electronic equipment with voice commands that uses an Arduino Uno microcontroller as a data processor, a power supply as a power source and a plug as output, and other electronic circuits as support for the system.

To activate the system, connect the system or a series of tools with a 5 Volt DC power supply with the Arduino Uno microcontroller or in another way connect the Arduino with a USB. To simulate electronic equipment controllers using voice commands based on Arduino Uno, namely by first making sure Bluetooth on the user's smartphone is active and connected to Bluetooth HC-05 after that activate Google Voice as input, then send voice commands via Google Voice then The user's voice will be processed at Atmega after which the relay module will work as a breaker or connector for the electric current which is connected to the plug so that the electronic device on the plug will be active from the one that is not active or vice versa from inactive to active.

\section{How the Tool Works}

1. Power Supply

Power Supply is a component that functions as a source of electric current for other components in the circuit (Sudarmaji, 2017). The power supply is not a component that produces an only electric current, but several power supplies produce mechanical energy and other energy. The power supply used is an adapter with a voltage of 220 Volt after entering the power supply, it is converted to 5 Volt DC, by the maximum capacity of the Arduino Uno R3 which is 12 Volts so that the components of the Electric Controller with Voice Command can work. If the voltage is less than 12 volts, the tool will still work but the results will be less than the maximum and if the adapter voltage exceeds the maximum capacity of 12 volts it will cause damage to Arduino Uno.

2. Input

Input in this circuit uses voice from the user through an application that is downloaded through the play store on the user's smartphone.

3. Process

In the Arduino Uno process section, it will process commands obtained from applications downloaded from Playstore.

4. Output

The output or the final result of this circuit uses the module relay as a breaker or connector that is connected to the power plug. 


\section{RESEARCH RESULTS AND DISCUSSION}

In this section, the author will carry out several testing schemes, which consist of input experiments, output experiments, and the results of all experiments or conclusions from these experiments.

\section{A. Input Experiment Results}

This section explains the results of the component test, namely the Bluetooth HC-05. The explanation in table 1 is that by the distance testing experiments that have been carried out, it can be concluded that the maximum distance for a smartphone with Bluetooth HC 05 is 20 meters. In the first experiment, the authors tested with a distance of 5 meters and one room with Bluetooth HC 05 , the results were connected and the device could work according to orders, in the second experiment with a distance of 10 meters while remaining in the same room with Bluetooth $\mathrm{HC} 05$, the results were Bluetooth and connected smartphones and devices. can work, while at a distance of 15 meters with a different smartphone position or outside the room where the Bluetooth is the result the smartphone and Bluetooth HC 05 are still connected so that the device continues to work, the author tests at a distance of 20 meters with the Bluetooth HC 05 position outside or in a different room with the smartphone, the results are still well connected and the device works normally, while at a distance of 15 meters with the Bluetooth HC-05 position and the smartphone in a different room, the result is Bluetooth is not interrupted or the connection is lost from the smartphone. This section shows the results of testing the power input connected to the appliance

Table 1. The experiment results of input sensor Bluetooth HC05

\begin{tabular}{cccc}
\multicolumn{4}{c}{ Bluetooth HC05 } \\
\hline No. & $\begin{array}{c}\text { Range } \\
\text { (meter) }\end{array}$ & \multicolumn{1}{c}{ Testing } & status \\
\hline 1 & 5 & $\begin{array}{l}\text { In the same room } \\
\text { with Bluetooth } \\
\text { In the same room } \\
\text { with Bluetooth } \\
\text { Outside the room } \\
\text { with no obstacles } \\
\text { to using the } \\
\text { Bluetooth } \\
\text { Outside the room } \\
\text { where Bluetooth } \\
\text { is located } \\
\text { Outside the room } \\
\text { with some } \\
\text { obstacles of using } \\
\text { the Bluetooth }\end{array}$ & Connected \\
\hline
\end{tabular}

The explanation in Table 2 is that the author tests the resource input experiment with 3 sources, namely, 9 Volt Alkaline Batteries, AC Current, and USB Port. The first experiment with a 9 Volt alkaline battery is an active tool but it only lasts a maximum of 4 hours on continuous use but the tool works less optimally because the resources obtained are very minimal. In the second experiment the testers took a power source from the old AC, the tool was active depending on the AC source because once the source is disconnected the tool will turn off but when using DC the tool works optimally. In the last experiment, the writer took the power source from the laptop via the USB port with the duration depending on the USB port connected, but the device did not work optimally because the powder obtained was very minimal.

Table 2. The experiment results on resource input

\begin{tabular}{|c|c|c|c|}
\hline \multicolumn{4}{|c|}{ Resources } \\
\hline No. & Resources & Status & Result \\
\hline 1 & $\begin{array}{l}\text { Alkaline } \\
\text { Battery } \\
\text { (9 Volt) }\end{array}$ & $<4$ jam & $\begin{array}{l}\text { The tool works less } \\
\text { optimally because } \\
\text { of the less power it } \\
\text { gets }\end{array}$ \\
\hline 2 & $\begin{array}{c}\text { A.C } \\
\text { (Alternating } \\
\text { Current) }\end{array}$ & Active & $\begin{array}{l}\text { The tool works } \\
\text { optimally because } \\
\text { of sufficient power }\end{array}$ \\
\hline 3 & USB Port & Active & $\begin{array}{l}\text { The tool does not } \\
\text { work optimally } \\
\text { because of the lack } \\
\text { of power it gets }\end{array}$ \\
\hline
\end{tabular}

The explanation in Table 3 is that the tester's voice input experiment was carried out on 4 light bulbs. The first experiment was on lamp one with the oneon-one light command to turn on the porch light and the one-off light command to turn off the porch light. The second experiment was on lamp two with the command for two lights to turn on the bathroom light and two lights off to turn off the bathroom lights. The third experiment was with three lights with a three-light command to turn on the toilet light and three lights to turn off the toilet light. In the fourth experiment, the four lights were on with the command to turn on four lights to turn on the living room lights and turn off the four lights to turn off the living room lights. Final experiment on all lights with the command turn on all lights to turn on all lights and all lights off to turn off all lights. 
Table 3. The results of the voice input experiment

\begin{tabular}{|c|c|c|c|}
\hline \multicolumn{4}{|c|}{ Voice Input } \\
\hline No. & $\begin{array}{c}\text { Voice } \\
\text { Command }\end{array}$ & Status light & Expectation \\
\hline 1 & $\begin{array}{l}\text { The } 1^{\text {st }} \text { lamp } \\
\text { was on }\end{array}$ & $\begin{array}{l}\text { The porch } \\
\text { light was on }\end{array}$ & $\begin{array}{l}\text { The porch light } \\
\text { was on }\end{array}$ \\
\hline 2 & $\begin{array}{l}\text { The } 1^{\text {st }} \text { lamp } \\
\text { was off }\end{array}$ & $\begin{array}{l}\text { The porch } \\
\text { light was off }\end{array}$ & $\begin{array}{l}\text { The porch light } \\
\text { was off }\end{array}$ \\
\hline 3 & $\begin{array}{l}\text { The } 2^{\text {nd }} \\
\text { lamp was on }\end{array}$ & $\begin{array}{l}\text { The living } \\
\text { room light } \\
\text { was on }\end{array}$ & $\begin{array}{l}\text { The living room } \\
\text { light is on }\end{array}$ \\
\hline 4 & $\begin{array}{l}\text { The } 2^{\text {nd }} \\
\text { lamp was off }\end{array}$ & $\begin{array}{l}\text { The living } \\
\text { room lights } \\
\text { were off }\end{array}$ & $\begin{array}{l}\text { The living room } \\
\text { lights were off }\end{array}$ \\
\hline 5 & $\begin{array}{l}\text { The } 3^{\text {rd }} \text { lamp } \\
\text { was on }\end{array}$ & $\begin{array}{l}\text { room lights } \\
\text { on }\end{array}$ & room lights on \\
\hline 6 & $\begin{array}{l}\text { The } 3^{\text {rd }} \text { lamp } \\
\text { was off }\end{array}$ & $\begin{array}{l}\text { room lights } \\
\text { off }\end{array}$ & room lights off \\
\hline 7 & $\begin{array}{l}\text { The } 4^{\text {th }} \text { lamp } \\
\text { was on }\end{array}$ & $\begin{array}{l}\text { The fan was } \\
\text { on }\end{array}$ & The fan was on \\
\hline 8 & $\begin{array}{l}\text { The } 4^{\text {th }} \text { lamp } \\
\text { was off }\end{array}$ & $\begin{array}{l}\text { The fan was } \\
\text { off }\end{array}$ & The fan was off \\
\hline 9 & $\begin{array}{l}\text { All the lights } \\
\text { were on }\end{array}$ & All were on & $\begin{array}{l}\text { All lights were } \\
\text { on }\end{array}$ \\
\hline 10 & $\begin{array}{l}\text { All the lights } \\
\text { were off }\end{array}$ & All were off & All lights are off \\
\hline
\end{tabular}

\section{B. Experimental results output}

In the output experiment in Table 4, the authors tested the lamp with the output on.

Table 4. Output Result Table

\begin{tabular}{|c|c|c|c|c|}
\hline no & Electronic & Command & $\begin{array}{c}\text { Early } \\
\text { electronic } \\
\text { state }\end{array}$ & $\begin{array}{c}\text { The final } \\
\text { electronic } \\
\text { state }\end{array}$ \\
\hline 1 & $\begin{array}{l}\text { The 1st } \\
\text { lamp }\end{array}$ & $\begin{array}{l}\text { The porch } \\
\text { light was } \\
\text { on }\end{array}$ & Off & On \\
\hline 2 & $\begin{array}{l}\text { The } 2 \text { nd } \\
\text { lamp }\end{array}$ & $\begin{array}{l}\text { The living } \\
\text { room } \\
\text { lights } \\
\text { were On }\end{array}$ & Off & On \\
\hline 3 & $\begin{array}{l}\text { The } 3^{\text {rd }} \\
\text { lamp }\end{array}$ & $\begin{array}{l}\text { The room } \\
\text { lights } \\
\text { were on }\end{array}$ & Off & On \\
\hline 4 & fan & $\begin{array}{l}\text { The fan } \\
\text { was on }\end{array}$ & Off & On \\
\hline
\end{tabular}

\section{B. Overall Experiment Results}

Table 5. Th overall experiment results

\begin{tabular}{|c|c|c|c|c|c|c|}
\hline $\begin{array}{l}\mathrm{N} \\
\mathrm{o}\end{array}$ & $\begin{array}{l}\text { Rang } \\
\text { e(M) }\end{array}$ & $\begin{array}{l}\text { Blueto } \\
\text { oth } \\
\text { status }\end{array}$ & $\begin{array}{l}\text { Voice } \\
\text { Com } \\
\text { mand }\end{array}$ & $\begin{array}{c}\text { Proc } \\
\text { ess } \\
\text { time }\end{array}$ & $\begin{array}{l}\text { Expect } \\
\text { ation }\end{array}$ & $\begin{array}{c}\text { Tool } \\
\text { stat } \\
\text { us }\end{array}$ \\
\hline 1 & 5 & $\begin{array}{l}\text { connec } \\
\text { ted }\end{array}$ & $\begin{array}{l}\text { turn } \\
\text { on } \\
\text { the } \\
\text { lights }\end{array}$ & $\begin{array}{l}2 \\
\text { seco } \\
\text { nds }\end{array}$ & $\begin{array}{l}\text { The } \\
\text { light } \\
\text { was } \\
\text { on }\end{array}$ & $\begin{array}{l}\text { Not } \\
\text { wor } \\
\text { king }\end{array}$ \\
\hline 2 & 10 & $\begin{array}{l}\text { connec } \\
\text { ted }\end{array}$ & $\begin{array}{l}\text { turn } \\
\text { off } \\
\text { the } \\
\text { lights }\end{array}$ & $\begin{array}{l}2 \\
\text { seco } \\
\text { nds }\end{array}$ & $\begin{array}{l}\text { Lights } \\
\text { were } \\
\text { off }\end{array}$ & $\begin{array}{l}\text { Not } \\
\text { wor } \\
\text { king }\end{array}$ \\
\hline 3 & $>15$ & $\begin{array}{l}\text { discon } \\
\text { nected }\end{array}$ & $\begin{array}{l}\text { Not } \\
\text { work } \\
\text { ing }\end{array}$ & $\begin{array}{l}\text { Not } \\
\text { wor } \\
\text { king }\end{array}$ & $\begin{array}{l}\text { Not } \\
\text { worki } \\
\text { ng }\end{array}$ & $\begin{array}{l}\text { Not } \\
\text { wor } \\
\text { king }\end{array}$ \\
\hline
\end{tabular}

The explanation in table 5 is the results of tests that have been carried out on all devices, both from the Bluetooth distance to the smartphone. The function of the tool is as expected. The test results will be entered into the table. In the first experiment, with a distance of 5 meters, the smartphone with Bluetooth status is still connected, after which a voice command is given, the device will process the command until the output light responds to the command it takes 2 seconds, but at a distance of more than 15 meters, the smartphone with Bluetooth means Bluetooth status will be disconnected. so that the tool will not respond to voice commands and does not process so that the status of the light state does not change.

\section{CONCLUSIONS AND SUGGESTIONS}

\section{CONCLUSION}

This electronic equipment controller with voice commands acts as a smart switch that can turn off or turn on electronic equipment according to user commands. So the problem is the factor of forgetting and being lazy to turn off electronic equipment when it is not in use or they are traveling outside, and it results in a waste of electrical energy or it can also cause a fire. The use of an Arduinobased Bluetooth connection is connected to a smartphone and this tool can also be used inside the house but in offices and large buildings.

\section{Suggestion}

This Arduino Uno-based electronic device controller can be developed into a remote controller based on the internet so that the distance is not limited while the user's smartphone is still connected to the internet. Can be developed using an android application and combined with a smart 
home project and more optimally you should take power from the AC.

\section{REFERENCE}

Aulia, S., Lifwarda, L., \& Yustini, Y. (2018). Pengenalan Bentuk Benda Berdasarkan Sinyal Suara dengan Transducer Mikrofon dan Teknologi Kinect. Jurnal Nasional Teknik Elektro, $7(3), \quad 191$. https://doi.org/10.25077/jnte.v7n3.600.201 8

Budiarto, J., \& Hadi, S. (2020). Sistem Kendali Peralatan Elektronik Rumah Tangga Berbasis Internet of Things Menggunakan Protokol MQTT Jurnal BITe: Jurnal Bumigora Information Technology Jurnal BITe: Jurnal Bumigora Information Technology. Jurnal BITe Vol.2 No.1 (Juni) 2020, Hal 1-11 Sistem, 2(1), $1-11$. https://doi.org/10.30812/bite.v2i1.799

Dani, A. W., Adriansyah, A., \& Hermawan, D. (2016). Perancangan Aplikasi Voice Command Recognition Berbasis Android Dan Arduino Uno. Jurnal Teknologi Elektro, 7(1), 11-19. https://doi.org/10.22441/jte.v7i1.811

Destiarini, \& Kumara, P. W. (2019). Robot Line Follower Berbasis Mikrokontroller Arduino Uno Atmega328. Jurnal Informanika, 5(1), 1825.

Faroqi, A., WS, M. S., \& Nugraha, R. (2016). Perancangan Sistem Kontrol Otomatis Lampu Menggunakan Metode Pengenalan Suara Berbasis Arduino. TELKA - Telekomunikasi, Elektronika, Komputasi Dan Kontrol, 2(2), 106-117.

https://doi.org/10.15575/telka.v2i2.31

Fatoni, A., \& Rendra, D. B. (2014). Perancangan Prototype Sistem Kendali Lampu Menggunakan Handphone Android Berbasis Arduino. Jurnal PROSISKO, 1(September), 2329.

Lubis, Z., Gultom, M. A., \& Annisa, S. (2019). Metode Baru Menyalakan Lampu Dengan Perintah Suara Berbasis Arduino Uno Menggunakan Smartphone. JET Uournal of Electrical Technology), 4(3). Retrieved from https://jurnal.uisu.ac.id/index.php/jet/articl e/view/2066

Manaor, A., Efendi, S., \& Informatika, P. T. (2017). Implementasi Pengendalian Lampu Otomatis Berbasis Arduino Menggunakan Metode Fuzzy Logic. Jurnal Penelitian Teknik Informatika Universitas Malikussaleh (TECHSI).

Mandey, J., \& Simbolon, M. (2018). Kontrol Lampu
Rumah Berbasis Smartphone Androidhome_Based Smartphone Controls Android Smartphone. Seminar Nasional Teknologi, 697-704.

Maulana, E., \& Rachmat Adi Purnama. (2017). Pemanfaatan Layanan SMS Telepon Seluler Berbasis Mikrokontroler Atmega328p Sebagai Sistem Kontrol Lampu Rumah. Jurnal Teknik Komputer, 3(1), 93-99.

Purnamasari, I., \& Rezasatria, M. (2019). Rancang Bangun Pengendali Kipas Angin Berbasis Mikrokontroller Atmega 16 Melalui Aplikasi Android Dengan Bluetooth. Simetris: Jurnal Teknik Mesin, Elektro Dan Ilmu Komputer, 10(1), 147-160. https://doi.org/10.24176/simet.v10i1.2883

Rusdi, M., \& Yani, A. (2018). Sistem Kendali Peralatan Elektronik Melalui Media Bluetooth Menggunakan Voice Recognition. Journal of Electrical Technology, 3(1), 27-33.

Sentosa, W., Putra, jean riko kurniawan, \& Wulandari, D. (2017). Perancangan Sistem Pembagi Daya Arus Listrik 3 Fasa Menggunakan Arduino Uno dan Bluetooth HC05 Berbasis Android. Intra-Tech, 1(2), 68-74.

Sudarmaji, S. (2017). Work System Analysis of Power Supply in Optimizing Electricity on Personal Computer (Pc). Turbo: Jurnal Program Studi Teknik Mesin, 6(2), 168-177. https://doi.org/10.24127/trb.v6i2.554

Warangkiran, I., Kaunang, I. S. T. G., Lumenta, A. S. M., \& St, A. M. R. (2014). Perancangan Kendali Lampu Berbasis Android. Jurnal Teknik Elektro Dan Komputer, 3(1), 65-72. https://doi.org/10.35793/jtek.3.1.2014.3827 